\title{
An inducible arylsulfatase of Volvox carteri with properties suitable for a reporter-gene system Purification, characterization and molecular cloning
}

\author{
Armin HALLMANN and Manfred SUMPER \\ Lehrstuhl Biochemie I, Universität Regensburg, Germany \\ (Received November 23, 1993/January 17, 1994) - EJB 93 1740/2
}

The multicellular green flagellate Volvox carteri synthesizes a periplasmic arylsulfatase in response to sulfur deprivation. The inducible enzyme has been purified to homogeneity and characterized. The corresponding gene and cDNA have been cloned. Determination of the sequence of genomic clones and comparisons to the cDNA sequence, revealed sixteen introns and seventeen exons that encode a 649-amino-acid polypeptide chain.

Since the arylsulfatase enzyme is readily assayed using chromogenic substrates, but is not detectable in cells grown in sulfate-containing medium, the gene encoding arylsulfatase may be useful as a reporter gene in $V$. carteri. In addition, the highly regulated promoter of the arylsulfatase gene suggests its suitability as a tool for producing inducible expression vectors for cloned genes.

The green algae of the genus Volvox are among the simplest multicellular organisms with only two cell types: somatic and reproductive cells. Therefore, they have been used as a model system for biochemical and physiological investigations (Kirk and Harper, 1986; Schmitt et al., 1992). A number of genes possibly involved in the control of developmental processes have been cloned (Ertl et al., 1992; Sumper et al., 1993; Tschochner et al., 1987; Mages et al., 1988). A large number of developmental mutants have been described (Starr, 1970; Huskey et al., 1979; Callahan and Huskey, 1980). However, a serious drawback for molecular biological studies with this organism was the lack of a transformation system. With the recent establishment of a transformation system (Schiedlmeier et al., 1994), this disadvantage no longer exists. In order to allow the application of efficient molecular genetic approaches, reporter genes as well as appropriate promoters working in this organism are now required.

Studies with the unicellular alga Chlamydomonas reinhardtii suggest arylsulfatase as an attractive reporter-gene system, since chimeric genes incorporating the Chlamydomonas arylsulfatase-coding sequence and Chlamydomonas tubulin promoters can be expressed (Davies et al., 1992). In contrast, attempts to isolate stable transformants, either from the unicellular alga Chlamydomonas (Rochaix et al., 1984) or from the multicellular alga Volvox (Mages, 1990), failed with heterologous gene constructs. Therefore, a homologous reporter-gene system also appears to be necessary for Volvox.

Correspondence to A. Hallmann, Lehrstuhl Biochemie I, Universität Regensburg, D-93053 Regensburg, Germany

Abbreviations. PCR, polymerase chain reaction; RACE, rapid amplification of cDNA ends.

Enzymes. Arylsulfatase (EC 3.1.6.1); trypsin (EC 3.4.21.4).

Note. The novel nucleotide sequence data published here have been submitted to the EMBL Data Library and are available under accession number X77214.
The arylsulfatase is an inducible enzyme which is only expressed under conditions of sulfur starvation. A number of chromogenic substrates are available allowing for the easy determination of enzyme activity. An arylsulfatase activity, inducible only under conditions of sulfur starvation, is also detectable in $V$. carteri (unpublished results). The enzyme can easily be assayed in whole cells or in extracts. These features suggest that the arylsulfatase gene may also serve as a valuable tool in transformation experiments in $V$. carteri. The coding sequence of the arylsulfatase could be used as a reporter gene and its promoter would be an attractive regulatory element for fusion with cloned genes, allowing their expression to be induced by sulfate starvation. Attempts to clone the Volvox enzyme with the heterologous cDNA probe from $C$. reinhardtii were unsuccessful. Therefore, we obtained amino acid sequence data for the purified enzyme and used this information for cloning both the genomic DNA and the cDNA encoding this enzyme.

\section{MATERIALS AND METHODS}

\section{Culture conditions}

$V$. carteri forma nagariensis strain HK10 (female) was obtained from the Culture Collection of Algae at the University of Texas (Dr R. C. Starr). Synchronous cultures were grown in Volvox medium (Provasoli and Pintner, 1959) at $28^{\circ} \mathrm{C}$ in an 8-h dark/16-h light $(10000 \mathrm{~lx})$ cycle (Starr and Jaenicke, 1974). In Volvox medium lacking sulfate, $\mathrm{MgSO}_{4}$ was replaced by $\mathrm{MgCl}_{2}$.

\section{Assay of arylsulfatase activity}

Arylsulfatase activity was measured using either 4-nitrocatechol sulfate or 5-bromo-4-chloro-3-indolyl sulfate. With 4-nitrocatechol sulfate, the assay contained $5 \mathrm{mM}$ substrate, $50 \mathrm{mM}$ Tris/ $\mathrm{HCl}, \mathrm{pH} 8.0$, and enzyme in a final volume of 
$100 \mu \mathrm{l}$. After incubation at $37^{\circ} \mathrm{C}$ for $15 \mathrm{~min}$, the reaction was stopped by adding $1 \mathrm{ml} 1 \mathrm{M} \mathrm{NaOH}$ and the liberated 4-nitrocatechol was quantified by measuring the absorbance at $515 \mathrm{~nm}$. This assay was performed with extracts and column eluates.

Whole spheroids, incubated in sulfate-free medium for more than $5 \mathrm{~h}$, were cultivated in microtiter wells in $500 \mu \mathrm{l}$. $4 \mu \mathrm{l} 30 \mathrm{mM}$ 5-bromo-4-chloro-3-indolyl sulfate was added and cultures were incubated at $28^{\circ} \mathrm{C}$ for $2 \mathrm{~h}$. Algae expressing arylsulfatase were identified by their blue color.

For an activity stain in SDS/polyacrylamide gels, arylsulfatase-containing fractions were subjected to standard SDS/PAGE ( $8 \%$ polyacrylamide; Laemmli, 1970, 1977), without heating the probes to $95^{\circ} \mathrm{C}$. After electrophoresis, the gels were soaked in $100 \mathrm{mM}$ Tris/ $\mathrm{HCl}, \mathrm{pH} 8.0$, for $20 \mathrm{~min}$ and 5-bromo-4-chloro-3-indolyl sulfate was added to a final concentration of $0.5 \mathrm{mM}$. The gels were incubated at $20^{\circ} \mathrm{C}$ for the times indicated.

\section{Purification of arylsulfatase}

Volvox spheroids (HK10) from three 20-1 cultures were collected on a nylon screen. After extensive washing with Volvox medium lacking sulfate, the algae were incubated in sulfate-free medium under standard conditions for a further three days. At the end of this period, the spheroids were collected. Solid $\mathrm{NaCl}$ was added to a final concentration of $400 \mathrm{mM}$, and the culture was stirred for $15 \mathrm{~h}$ at $4^{\circ} \mathrm{C}$. The suspension was filtered through 100-, 40- and 10- $\mu \mathrm{m}$ mesh nylon cloths to remove the Volvox spheroids. Ammonium sulfate was added to $40 \%$ saturation, and the solution was stirred at $4^{\circ} \mathrm{C}$ for $20 \mathrm{~min}$. After centrifugation for $20 \mathrm{~min}$ at $8000 \mathrm{~g}$, the supernatant was brought to $70 \%$ saturation with ammonium sulfate, incubated at $4^{\circ} \mathrm{C}$ for $2 \mathrm{~h}$, and centrifuged for $1 \mathrm{~h}$ at $11000 \mathrm{~g}$. Precipitated protein containing arylsulfatase activity was suspended in $50 \mathrm{mM}$ Tris/ $\mathrm{HCl}, \mathrm{pH} 8.0$. After extensive dialysis against the same buffer, the solution was passed through a $\mathrm{C}_{18}$ (octadecylsilane) cartridge (Millipore) and applied to a column of blue Sepharose CL-6B (Pharmacia) equilibrated with $50 \mathrm{mM}$ Tris/HCl, $\mathrm{pH} 8.0$. The column was washed with two volumes of the same buffer and was developed by applying a linear gradient of $\mathrm{NaCl}$ (in $50 \mathrm{mM}$ Tris/ $\mathrm{HCl}, \mathrm{pH} 8.0$ ) from $0-400 \mathrm{mM}$. The arylsulfatase eluted at $130-200 \mathrm{mM} \mathrm{NaCl}$. The protein was collected by precipitation with ammonium sulfate ( $70 \%$ saturation). The pellet was dissolved in a minimal volume of $50 \mathrm{mM}$ Tris/ $\mathrm{HCl}, \mathrm{pH} 8.0,100 \mathrm{mM} \mathrm{NaCl}$ and applied to a Superose 12 HR 10/30 FPLC column (Pharmacia) equilibrated in the same buffer. The fractions containing enzyme activity were concentrated and desalted in a microconcentrator (Centricon 30 , Amicon). The concentrated material was applied to a $8 \%$ SDS/polyacrylamide gel and arylsulfatase was eluted from the gel by diffusion. Typically, the yield was $50-100 \mu \mathrm{g}$ homogenous arylsulfatase. For peptide analysis, the arylsulfatase was digested without elution from the SDS/polyacrylamide gel.

\section{Proteolytic digestion and separation of peptides}

$30 \mu \mathrm{g}$ arylsulfatase was analysed by SDS/PAGE $(8 \%$ polyacrylamide) and stained with Coomassie blue. The gel slice containing arylsulfatase was crushed and totally destained by incubations in 30\% methanol, followed by $7 \%$ acetic acid containing $50 \%$ methanol and finally by $7 \%$ acetic acid (each for $2 \mathrm{~h}$ ). The gel was soaked in $90 \%$ ethanol for $2 \mathrm{~h}$ and dried by lyophilization. $4 \mu \mathrm{g}$ trypsin in $800 \mu \mathrm{l}$ $0.2 \mathrm{M} \mathrm{NH}_{4} \mathrm{HCO}_{3}$ was added and the gel material was incubated at $37^{\circ} \mathrm{C}$ overnight. The resulting peptide mixture was eluted from the gel by diffusion in $0.2 \mathrm{M} \mathrm{NH}_{4} \mathrm{HCO}_{3}$ containing 50\% acetonitrile. The eluate was passed through a $0.22-\mu \mathrm{m}$ pore-size filter (Millipore), adjusted to $0.1 \%$ trifluoroacetic acid and dried by lyophilization. The peptides were dissolved in $6 \mathrm{M}$ guanidine/ $\mathrm{HCl} / 0.1 \% \mathrm{CF}_{3} \mathrm{CO}_{2} \mathrm{H}$ and fractionated by reverse-phase HPLC (Smart system, Pharmacia) on a $\mu \mathrm{RPC} \mathrm{C}_{2} / \mathrm{C}_{18}, 3-\mu \mathrm{m}$ particle-size column (Pharmacia). The peptides were eluted by a $30-\mathrm{min}$ linear gradient of 5$40 \%$ acetonitrile in $0.1 \% \mathrm{CF}_{3} \mathrm{CO}_{2} \mathrm{H}$ with a flow rate of $200 \mu \mathrm{l} / \mathrm{min}$.

The peptides were sequenced by Edman degradation using an automated gas-phase peptide sequencer (Applied Biosystems, Inc.).

\section{Generation of a cDNA probe by PCR}

RNA was extracted as described by Kirk and Kirk (1985) from Volvox spheroids incubated in sulfate-free medium for $15 \mathrm{~h}$. A cDNA library covalently linked to magnetic beads was constructed according to the instructions of the manufacturer of the magnetic beads (Deutsche Dynal). Polymerasechain-reaction (PCR) amplification was performed in $100 \mu \mathrm{l}$ containing the following reagents: $50 \mathrm{mM}$ Tris/ $\mathrm{HCl}, \mathrm{pH} 8.5$, $50 \mathrm{mM} \mathrm{NaCl}, 2.5 \mathrm{mM} \mathrm{MgCl}, 2 \mathrm{mM}$ dithiothreitol, $2 \mu \mathrm{l}$ suspension of the cDNA library covalently linked to magnetic beads, $400 \mathrm{pmol}$ degenerate sense primer TTYGAYTAYAAYAA, 400 pmol degenerate antisense primer ATYTGNGCRTARAA, $100 \mu \mathrm{M}$ dNTP and $2.5 \mathrm{U}$ Taq polymerase. 40 cycles of PCR amplification (Perkin-Elmer cycler model 480 ) were performed (denaturation at $94^{\circ} \mathrm{C}$ for $45 \mathrm{~s}$, annealing at $45^{\circ} \mathrm{C}$ for $30 \mathrm{~s}$, and extension at $72^{\circ} \mathrm{C}$ for $20 \mathrm{~s}$ ). The resulting 146-bp DNA fragment was ligated into the SmaI site of pUC18 and was sequenced.

\section{Cloning of the arylsulfatase gene}

The $V$. carteri genomic library in $\lambda$ EMBL 3 (Frischauf et al., 1983), described by Ertl et al. (1989), was used to clone the arylsulfatase gene. The screening and cloning procedures followed standard techniques (Sambrook et al., 1989). DNA sequencing was performed by the dideoxynucleotide chaintermination method (Sanger et al., 1977) using T7 DNA polymerase (Pharmacia). Synthetic oligonucleotides were used throughout to sequence the arylsulfatase gene.

\section{PCR amplification of arylsulfatase cDNA fragments}

The cDNA library covalently linked to magnetic beads was used to generate cDNA fragments of arylsulfatase by PCR using specific oligonucleotide primers. The rapid amplification of cDNA ends (RACE)-PCR technique was performed as described by Frohman et al. (1988). The PCR fragments were ligated into the SmaI site of pUC18. Synthetic oligonucleotides were used to sequence the arylsulfatase cDNA fragments in both directions.

\section{PCR with RNA from twenty Volvox spheroids}

Twenty Volvox spheroids, after their release from the mother spheroid, were selected under the stereo microscope and transferred into $20 \mu \mathrm{l}$ sterile $50 \mathrm{mM}$ Tris/ $\mathrm{HCl}, \mathrm{pH} 8.0$, $300 \mathrm{mM} \mathrm{NaCl}, 5 \mathrm{mM}$ EGTA and 2\% SDS (buffer A). After 
$10 \min$ at $30^{\circ} \mathrm{C}$, Volvox spheroids were removed under the stereo microscope and RNA was precipitated with $60 \mu$ l ethanol. The washed precipitate ( $70 \%$ ethanol), was dissolved in $10 \mu \mathrm{l}$ reverse-transcriptase buffer, containing $50 \mathrm{mM}$ Tris/ $\mathrm{HCl}$ (pH 8.3), $40 \mathrm{mM} \mathrm{KCl}, 6 \mathrm{mM} \mathrm{MgCl}_{2}, 1 \mathrm{mM}$ dithiothreitol, $10 \mathrm{U}$ RNAguard (Pharmacia), $1 \mathrm{mM}$ each dNTP and 50 pmol antisense primer (5'-TTATCGGACACGTCAGC, amino acid positions $260-265)$. Reverse transcription was performed with $100 \mathrm{U}$ Moloney murine leukemia virus reverse transcriptase (Pharmacia) for $60 \mathrm{~min}$ at $40^{\circ} \mathrm{C}$; $90 \mu \mathrm{l}$ $50 \mathrm{mM}$ Tris/ $\mathrm{HCl}, \mathrm{pH} 8.5,50 \mathrm{mM} \mathrm{NaCl}, 2.5 \mathrm{mM} \mathrm{MgCl}$, $2 \mathrm{mM}$ dithiothreitol (buffer B) containing $50 \mathrm{pmol}$ sense primer (5'-GCTTCTATTCCACTGACG, amino acid positions $177-183$ ) was added, and 38 cycles of PCR amplification $\left(94^{\circ} \mathrm{C}, 45 \mathrm{~s} ; 52^{\circ} \mathrm{C}, 30 \mathrm{~s} ; 72^{\circ} \mathrm{C}, 45 \mathrm{~s}\right)$ were performed.

\section{Assays for substrate specificities}

$0.01-0.1 \mu \mathrm{mol}$ different substances were incubated with $0.1 \mathrm{U}$ arylsulfatase for $15 \mathrm{~h}$ at $37^{\circ} \mathrm{C}$. Subsequently, product formation was analysed by the following steps. Tyrosine and tyrosine sulfate were analysed by TLC (Kieselgel 60, Merck) in 1-butanol/acetic acid/water $(4: 1: 1$, by vol.) and were visualized by the ninhydrin reaction. Galactose and galactose sulfate (D-galactose 6-sulfate) were separated by TLC (Kieselgel 60 , Merck) in acetonitrile/water $(17: 3$, by vol.) and were visualized by the orcinol/sulfuric acid stain (Vaskovsky et al., 1970). Dextran and dextran sulfate were separated by anion-exchange chromatography. QAE A-25 Sephadex (Pharmacia), equilibrated in $20 \mathrm{mM}$ Tris/ $\mathrm{HCl}, \mathrm{pH} 8.0$, quantitatively binds dextran sulfate, whereas dextran appears in the flow-through fraction and was assayed with phenol/sulfuric acid (Dubois et al., 1956). Inorganic sulfate was determined by the rhodizonate assay (Terho and Hartiala, 1971). Adenosine $5^{\prime}$-phosphosulfate and AMP were separated by TLC [poly(ethyleneimine)-cellulose with fluorescence indicator dye, Schleicher \& Schiill] in $1.75 \mathrm{M} \mathrm{LiCl} / 2 \mathrm{M}$ formic acid and visualized under ultraviolet light at $254 \mathrm{~nm}$. Only tyrosine sulfate was a substrate. Under the conditions used, a quantitative conversion to tyrosine was achieved.

\section{Pulse labelling and preparation of a crude cell lysate}

Pulse labelling of $V$. carteri spheroids with $\left[{ }^{35} \mathrm{~S}\right]$ sulfate was performed as described by Wenzl and Sumper (1986). After extensive washing with Volvox medium lacking sulfate, the labeled spheroids were disintegrated by ultrasonic treatment ( $30 \mathrm{~s}$ total).

\section{RESULTS}

\section{Purification of arylsulfatase}

Independent of the developmental stage, synthesis of an arylsulfatase is induced in $V$. carteri in response to sulfur deprivation (unpublished results). This property was used for the isolation of the enzyme. Volvox spheroids were cultivated in sulfate-free medium for three days and were harvested. Extraction of the spheroids with $400 \mathrm{mM} \mathrm{NaCl}$ removed most of the arylsulfatase activity from the extracellular matrix. The enzyme solution was fractionated and precipitated with ammonium sulfate $(40-70 \%$ saturation), desalted by dialysis and passed through a reverse-phase $C_{18}$ cartridge (Fig. 1) that did not adsorb the enzyme. The flow-through was applied to a column of blue Sepharose. After extensive

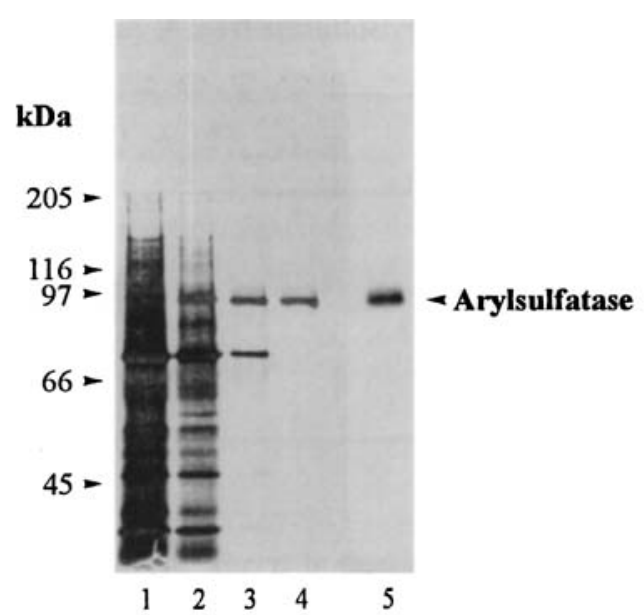

Fig. 1. The purification of arylsulfatase. SDS/PAGE $(8 \%$ polyacrylamide) was performed without heat treatment of the samples. The preparation after the following steps is shown: $\mathrm{C}_{18}$ cartridge (lane 1); blue Sepharose column (lane 2); gel filtration (Iane 3); final preparative SDS/PAGE (lane 4). Lanes 1-4 were stained with silver. Lane 5 shows an activity stain of the purified arylsulfatase in the same SDS/polyacrylamide gel (see Materials and Methods section). Each lane of the gel was loaded with the same amount of arylsulfatase activity. The molecular mass of marker proteins are indicated.

washing with $50 \mathrm{mM}$ Tris/ $\mathrm{HCl}$, $\mathrm{pH} 8.0$, the column was developed by applying a linear $\mathrm{NaCl}$ gradient of $0-400 \mathrm{mM}$. Arylsulfatase activity was eluted from the column at 130 $200 \mathrm{mM} \mathrm{NaCl}$ (Fig. 1). The concentrated eluate was further fractionated by gel filtration over a Superose 12 column (Fig. 1). A final purification to homogeneity was achieved by preparative SDS/PAGE (Fig. 1). The yield of enzyme and the degree of purification achieved in each step are shown in Table 1. Remarkably, arylsulfatase activity was not inhibited in the presence of even $1 \%$ SDS or $1 \% \mathrm{~N}$-lauroylsarcosine. Therefore, we were able to localize arylsulfatase that had been electrophoresed in standard SDS/PAGE (without prior heat treatment) by staining for enzymic activity (Fig. 1). Native arylsulfatase exhibits an apparent molecular mass of approximately $95 \mathrm{kDa}$. Heat treatment causes the loss of enzyme activity (data not shown) and, as expected, a higher mobility in SDS/PAGE (apparent molecular mass approximately $70 \mathrm{kDa})$.

\section{Protein chemical studies}

Automated Edman degradation of the purified arylsulfatase showed that its $\mathrm{N}$-terminal amino acid sequence was XXRPNFVVIFTDDQ. In order to get additional sequence information, arylsulfatase, localized in a SDS/polyacrylamide gel by the activity stain, was digested by incubating the corresponding gel slice with trypsin. The resulting peptide mixture was eluted from the polyacrylamide gel and chromatographed by reverse-phase $\mathrm{C}_{2} / \mathrm{C}_{18} \mathrm{HPLC}$. The components of resolved peaks were directly subjected to amino acid sequence analysis on an automated gas-phase sequencer. The amino acid sequence data obtained are summarized in Table 2. The amino acid sequence of peptide 8 corresponds to the $\mathrm{N}$-terminal amino acid sequence. Peptide 3 includes a posttranslational modification at amino acid position 8 which indicates a N-glycosylation site. 
Table 1. Purification of arylsulfatase from $V$. carteri. Enzyme units are given as $\mu \mathrm{mol}$ 4-nitrocatechol sulfate hydrolyzed/h at $\mathrm{pH} 8.0$ and at $37^{\circ} \mathrm{C}$ (15 min assay).

\begin{tabular}{lcccc}
\hline Fraction after & Total protein & $\begin{array}{l}\text { Total enzyme } \\
\text { activity }\end{array}$ & $\begin{array}{l}\text { Specific enzyme } \\
\text { activity }\end{array}$ \\
\hline & $\mathrm{mg}$ & $\mathrm{U}$ & $\mathrm{U} / \mathrm{mg}$ & $\%$ \\
$\mathrm{NaCl}$ extraction & 123 & 37 & 0.3 & 100 \\
$\mathrm{C}_{18}$ cartridge & 23 & 28 & 1.2 & 76 \\
Blue-Sepharose column & 3 & 14 & 25 & 38 \\
Gel filtration & 0.4 & 10 & 40 & 11 \\
Final SDS/PAGE & 0.1 & 4 & 47 & 11 \\
\hline
\end{tabular}

Table 2. Amino acid sequences of tryptic peptides derived from arylsulfatase.

\begin{tabular}{ll}
\hline Peptide & Amino acid sequence \\
\hline 1 & ILXPEGSVNSWXQSLD \\
2 & TFDYNNPGFSR \\
3 & GQFSHNT--FTDVLGPHGGYAK \\
4 & NLYEADVSDKPAWI \\
5 & XAVAXGKPFYAQISPXAP \\
6 & SLASVDELIDR \\
7 & NGATPNIYPGFYSTDVIADK \\
8 & HQRPNFVVIFTD \\
9 & HWELFSDATLPEGTSHK \\
10 & VVATLQEAGVLDNTYLIY \\
\hline
\end{tabular}

\section{Generation of a 146-bp cDNA probe by PCR}

The amino acid information from the tryptic peptide TFDYNNPGFSR was used to synthesize the sense oligonucleotide primer TTYGAYTAYAAYAA corresponding to amino acids at positions 2-5. The antisense primer ATYTGNGCRTARAA was derived from amino acid positions $9-13$ of the peptide XAVAXGKPFYAQISPXAP. Using these primers, a 146-bp fragment could be amplified by PCR from a cDNA library covalently linked to magnetic beads. DNA sequence analysis confirmed that this fragment did indeed encode for a region of the arylsulfatase polypeptide.

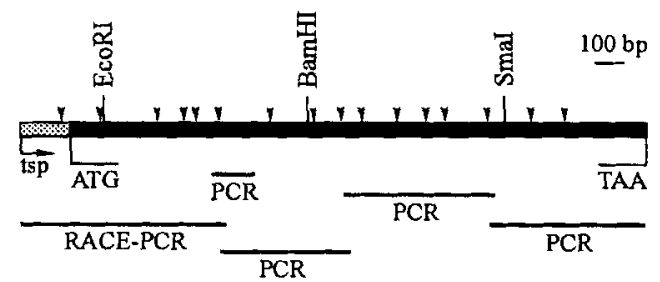

Fig. 3. The PCR strategy used to obtain the complete nucleotide sequence of arylsulfatase cDNA. The positions of introns are given ( $)$. tsp, transcription start point.

\section{Genomic clones encoding arylsulfatase}

A genomic library of $V$. carteri constructed in the vector $\lambda$ EMBL 3 was screened using the 146-bp cDNA as a probe. Clones $\lambda \mathrm{Ar} 52$ and $\lambda \mathrm{Ar} 41$, hybridizing to the $146-\mathrm{bp}$ cDNA probe, were first isolated. However, neither of these clones contained the $3^{\prime}$ terminal end of the arylsulfatase gene. Therefore, the insert of plasmid pVAr4BS11, derived from $\lambda \mathrm{Ar} 41$ and containing the region shown in Fig. $2 \mathrm{~A}$, was used for an additional screening of the $\lambda \mathrm{EMBL} 3$ library. This produced $\lambda$ Ar72, a clone that contains the complete arylsulfatase gene. Partially overlapping fragments from $\lambda$ Ar41 and $\lambda$ Ar72 allowed the determination of the complete sequence of the $V$. carteri arylsulfatase gene, including the $5^{\prime}$ and $3^{\prime}$ untranslated regions. Exon-intron organization was deduced by comparison of genomic and cDNA sequences. Fig. 2B

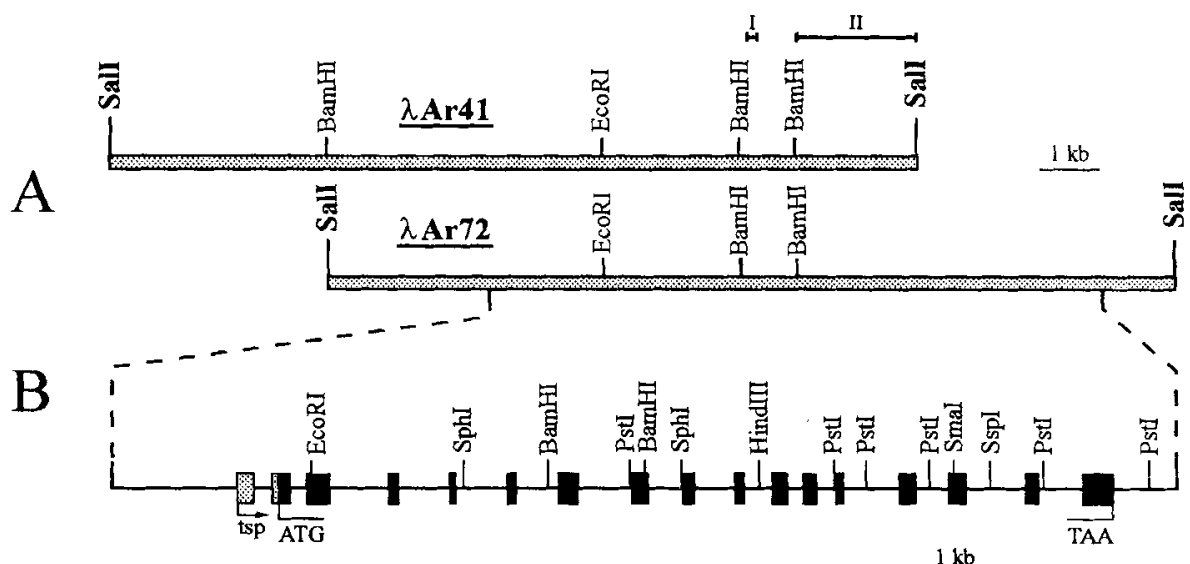

Fig. 2. (A) Physical map of two overlapping arylsulfatase genomic clones $\lambda$ Ar41 and $\lambda$ Ar72 and (B) derived intron-exon structure of the arylsulfatase gene. In A, the 146-bp PCR probe (I) and the insert of pVAr4BS11 (II) are indicated. Sites linking insert and vector DNA are given in bold-face type. tsp, transcription start point. 
1 ATG TTG CAA CGA TTG GTC GTT GCA TTA TGC CTG CTT GGG TTT GCG GCC TTG ACT GCG GCC GCC GCA ${ }^{2}$ CAT

\begin{tabular}{llllllllllllllllllllllllllll}
1 & $M$ & $L$ & $Q$ & $R$ & $L$ & $V$ & $V$ & $A$ & $L$ & $C$ & $L$ & $L$ & $G$ & $F$ & $A$ & $A$ & $L$ & $T$ & $A$ & $A$ & $A$ & $A$ & $H$ \\
\hline
\end{tabular}

70 CAG CGT CCA AAC TTC GTC GTT ATT TTC ACT GAT GAC CAA GAT GGA ATT CAG AAC_TCC_ACG CAT CCG CGC

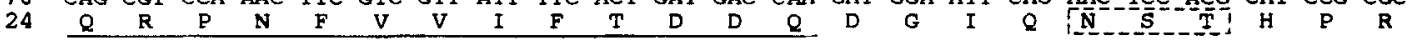

139 TAC CAG CCC AAG CTG CAT GAG CAC ATC CGC TAC CCC GGC ATT GAG CTC AAG AAC TAC TTC GTC ACG ACT

47 Y $Q$ P

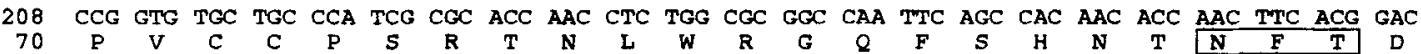

277 GTC CTT GGG CCC CAC GGC GGC TAC GCA AAG TGG AAG TCG CTG GGC ATC GAT AAG TCC TAC CTG CCT GTC

$\begin{array}{lllllllllllllllllllllllllll}93 & V & I & G & P & H & G & G & \mathbf{Y} & A & K & W & K & S & L & G & I & D & K & S & Y & L & P & V\end{array}$

346 TGG CTA CAG AAC CTG GGC TAC AAC ACT TAC TAC GTT GGG AAG TTC CTT GTG GAC TAT TCG GTC TCC AAC

415 TAT CAA AAT GTG CCT GCT GGG TGG ACG GAC ATA GAC GCT CTG GTT ACG CCA TAC ACA TTC GAC TAC AAC

$\begin{array}{llllllllllllllllllllllllllll}139 & \text { Y } & Q & \text { N } & \text { V } & \text { P } & \text { A } & G & \text { W } & \text { T } & \text { D } & \text { I } & \text { D } & \text { A } & \text { L } & \text { V } & \text { T } & \text { P } & \text { Y } & \text { T } & \text { F } & \text { D } & \text { Y } & \text { N }\end{array}$

484 AAC CCC GGC TTC TCC AGG AAC GGT GCC ACA CCC AAC ATC TAC CCC GGC TTC TAT TCC ACT GAC GTC ATC

\begin{tabular}{lllllllllllllllllllllllll}
162 & $\mathbf{N}$ & $\mathbf{P}$ & $G$ & $\mathbf{F}$ & $\mathbf{S}$ & $\mathbf{R}$ & $\mathbf{N}$ & $G$ & $\mathbf{A}$ & $\mathbf{T}$ & $\mathbf{P}$ & $\mathbf{N}$ & $\mathrm{I}$ & $\mathbf{Y}$ & $\mathbf{P}$ & $\mathrm{G}$ & $\mathbf{F}$ & $\mathbf{Y}$ & $\mathbf{S}$ & $\mathbf{T}$ & $\mathbf{D}$ & $\mathrm{V}$ & $\mathrm{I}$ \\
\hline
\end{tabular}

553 GCG GAC AAG GCG GTG GCC CAG ATA AAG ACA GCG GTG GCG GCC GGG AAG CCC TTC TAT GCG CAG ATC TCC

\begin{tabular}{llllllllllllllllllllllllllll}
185 & $A$ & $D$ & $K$ & $A$ & $V$ & $A$ & $Q$ & $I$ & $K$ & $T$ & $A$ & $V$ & $A$ & $A$ & $G$ & $K$ & $P$ & $F$ & $Y$ & $A$ & $Q$ & $I$ & $S$ \\
\hline
\end{tabular}

622 CCC ATC GCT CCA CAC ACG AGC ACA CAG ATC TAT TTC GAC CCG GTG GCG AAT_GCC_ACC AAG ACT TTC TTC

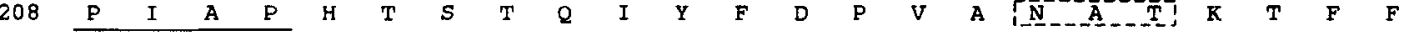

691 TAC CCG CCC ATC CCC GCC CCG CGG CAC TGG GAG CTC TTC TCC GAC GCC ACA CTG CCC GAA GGC ACA TCC

\begin{tabular}{lllllllllllllllllllllllll}
231 & $Y$ & $P$ & $P$ & $I$ & $P$ & $A$ & $P$ & $R$ & $H$ & $W$ & $E$ & $L$ & $F$ & $S$ & $D$ & $A$ & $T$ & $L$ & $P$ & $E$ & $G$ & $T$ & $S$ \\
\hline
\end{tabular}

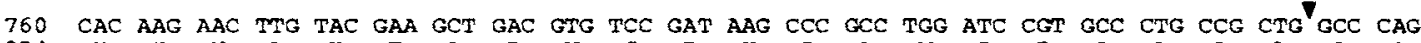

$\begin{array}{llllllllllllllllllllllllll}254 & H & \text { K } & \text { N } & \text { L } & \text { Y } & \text { E } & \text { A } & \text { D } & \text { V } & \text { S } & \text { D } & \text { K } & \text { P } & \text { A } & \text { W } & \text { I } & \text { R } & \text { A } & \text { L } & \text { P } & \text { L } & \text { A } & Q\end{array}$

829 CAG AAC AAC_CGC_ACC TAT TTG GAA GAG GTG TAC CGC CTG AGG CTG CGA TCG CTG GCC TCC GTG GAC GAG

$\begin{array}{llllllllllllllllllll}277 & Q & N & N & & \end{array}$

898 CTG ATC GAC CGA GTG GTG GCA ACA CTT CAG GAA GCC GGC GTC CTC GAC AAC ACA TAC CTC ATC TAC TCC

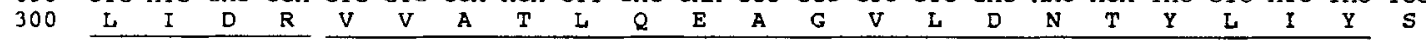

967 GCC GAT AAC GGC TAC CAC GTC GGC ACC CAC CGC TTC GGT GCT GGC AAG GTG ACT GCT TAC GAT GAG GAC

$\begin{array}{llllllllllllllllllllllll}323 & A & D & \text { N } & G & Y & H & \text { V } & G & T & \text { H } & \text { R } & \text { F } & G & \text { A } & G & \text { K } & \text { V } & \text { T } & \text { A } & \text { Y } & \text { D } & \text { E } & \text { D }\end{array}$

1036 CTC CGA GTG CCC TTC CTC ATC CGG GGT CCT GGA ATC CGA GCG TCA CAC AGC GAT AAG CCA GCT AAC AGC

$\begin{array}{lllllllllllllllllllllllllll}346 & \text { L } & \text { R } & \text { V } & \text { P } & \text { F } & \text { L } & \text { I } & \text { R } & \text { G } & \text { P } & \text { G } & \text { I } & \text { R } & \text { A } & \text { S } & \text { H } & \text { S } & \text { D } & \text { K } & \text { P } & \text { A } & \text { N } & S\end{array}$

1105 AAG GTG GGG CTT CAT GTG GAC TTP GCA CCC ACC ATC CTG ACT TTG GCG GGT GCT GGA GAC CAA GTG GGT

1174 GAC AAG GCG CTG GAC GGC ACA CCG CTG GGT CTT TAC GCC AAT GAT GAC GGC AAC CTC CTC GCG GAC TAC

$\begin{array}{llllllllllllllllllllllll}392 & D & K & A & L & D & G & T & P & \text { L } & G & \text { L } & Y & A & N & D & D & G & N & \text { L } & \text { L } & \text { A } & \text { D } & Y\end{array}$

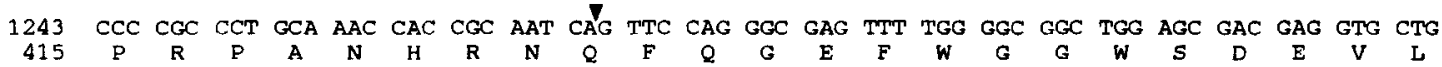

1312 CAC CAC ATC CCG CGC TAC ACG AAT_AAC_TCC TGG AAG GCC GTA CGG GTG TAC GAC GAG GAC AAC CAG CAG

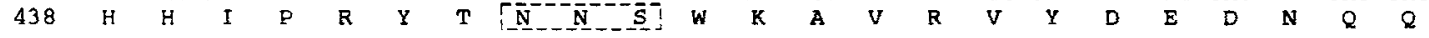

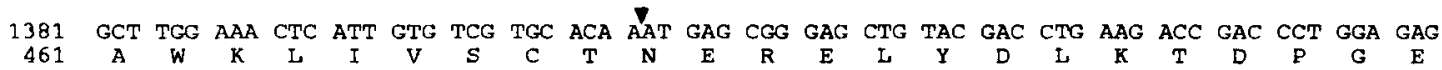

1450 CTT TGC AAT ATC TAC AAC_AAG_ACC CGG GCC GCT GTT CGG ACC AGG CTT GAA GCG CTT CTG GCG GTT CTG

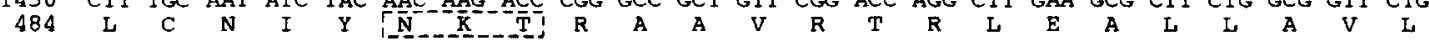

1519 GTG GTG TGC AAG GGC GAA AGT TGC ACG AAC CCA TGG AAG ATC CTC CAT CCA GAA GGT TCC GTC AAC TCT

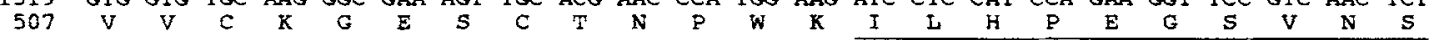

1588 TGG AAC_CAG_TCC TTG GAC CGG AAA TAC GAC AAG TAC TAC GCC AAC GTC GCA CCC TTC CAG TAT AGG ACT

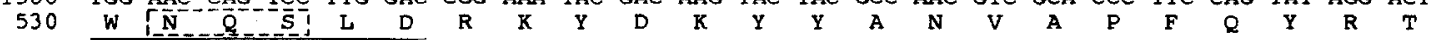

1657 TGC TTG CCG TAC CAG GAC CAC AAC AAC GAG GTT TCT GCC TTC CGA TCG ACA GTG GCG GCG GCA GCG GCG

$\begin{array}{llllllllllllllllllllllll}553 & \text { C } & \text { L } & \text { P } & \text { Y } & \text { Q } & \text { D } & \text { H } & \text { N } & \text { N } & \text { E } & \text { V } & \text { S } & \text { A } & \text { F } & \text { R } & \text { S } & \text { T } & \text { V } & \text { A } & \text { A } & \text { A } & \text { A } & \text { A }\end{array}$

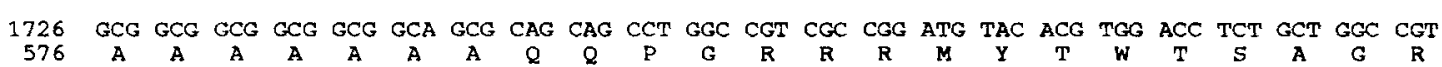

1795 CAA CTG TCC GCG ACA GCA TCG GCC ATC GCC ACC AGC CCA CAG CCG CGT TCG GAG CCG TTC GTT GCT GAG

$\begin{array}{llllllllllllllllllllllll}599 & Q & \text { L } & \text { S } & \text { A } & \text { T } & \text { A } & \text { S } & \text { A } & \text { I } & \text { A } & \text { T } & S & \text { P } & Q & \text { P } & \text { R } & \text { S } & \text { E } & \text { P } & \text { F } & \text { V } & \text { A } & E\end{array}$

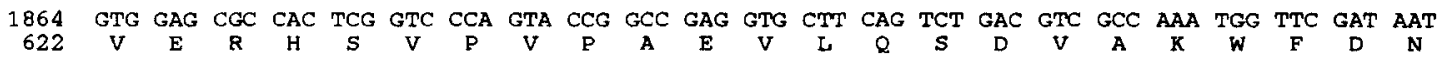

$\begin{aligned} 1933 & \text { CCG CTG GCC CTP GCT TAA } \\ 645 \text { P } & \text { L A A L A STOP }\end{aligned}$

Fig. 4. The nucleotide sequence of arylsulfatase cDNA and deduced amino acid sequence of arylsulfatase. The amino acid sequences confirmed from isolated peptides are underlined. Potential $(--)$ and confirmed $(-) \mathrm{N}$-glycosylation sites are boxed. The positions of introns are indicated $(\boldsymbol{\nabla})$. The cleavage site of the hydrophobic leader sequence is also marked $(\star)$. 


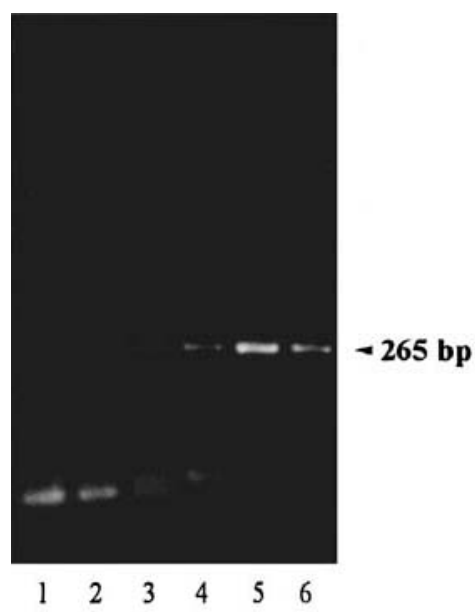

Fig. 5. The transcriptional control of arylsulfatase synthesis. RNA was extracted from twenty Volvox spheroids each grown in sulfate sufficient medium (lane 1) and subsequently starved for sulfate for $30 \mathrm{~min}$ (lane 2), 1 (lane 3), 3 (lane 4), 6 (lane 5) or $9 \mathrm{~h}$ (lane 6). After reverse transcription with an arylsulfatase-specific antisense oligonucleotide, a $265-\mathrm{bp}$ cDNA fragment of arylsulfatase was amplified by PCR. The sense and antisense oligonucleotides were selected from exons 7 and 8, respectively, to prevent amplification of genomic DNA. For details, see the Materials and Methods section.

summarizes the relative locations of the seventeen exons and sixteen introns.

\section{Cloning of arylsulfatase cDNA by PCR}

The complete cDNA sequence was determined by PCR using specific oligonucleotide primers, a cDNA library covalently linked to magnetic beads, and the strategy summarized in Fig. 3. The cDNA nucleotide sequence and the deduced amino acid sequence are shown (Fig. 4.); a total of seven potential N-glycosylation sites were found. With the protein chemical data, the glycosylation of at least one of these glycosylation sites has been confirmed (Table 2, peptide 3).

\section{Transcriptional control of arylsulfatase synthesis}

PCR was used to determine whether the sulfate-dependent control of arylsulfatase synthesis is exerted at the level of transcription. Using the PCR technique, mRNA from only a few algal spheroids is easily detectable (Ertl et al., 1992). RNA was extracted from twenty Volvox spheroids deprived of sulfate for $30 \mathrm{~min}, 1,3,6$ and $9 \mathrm{~h}$. Reverse transcription and subsequent PCR amplification of arylsulfatase cDNA yielded the results shown in Fig. 5. mRNA for arylsulfatase is virtually absent in sulfate-sufficient spheroids, but could be detected as early as $1 \mathrm{~h}$ after the initiation of sulfate deprivation; arylsulfatase mRNA reached a maximum level after $6 \mathrm{~h}$ of sulfate deprivation and subsequently declined. The maximum level of PCR product obtained was comparable to the level obtained with specific actin mRNA primers under the same experimental conditions. Thus, the arylsulfatase promoter should allow a high level of gene expression and the control of arylsulfatase production operates at the level of transcription.

\section{Location of the arylsulfatase}

The arylsulfatase gene encodes a $\mathrm{N}$-terminal leader sequence typical of a signal peptide, indicating an extracellular location of the arylsulfatase. However, $V$. carteri spheroids grown in sulfur-deficient medium do not secrete any enzyme with detectable activity into the culture fluid. All the enzyme activity remains associated with the spheroid, but can be extracted with $400 \mathrm{mM} \mathrm{NaCl}$. In a mutant strain called 'dissociator', which is unable to produce a structurally intact extracellular matrix and consequently dissociates into single cells shortly after the end of embryogenesis, large amounts of arylsulfatase activity are secreted into the culture medium. These results suggest deposition of the arylsulfatase within the extracellular matrix of the wild-type strain.

\section{Enzymic properties}

\section{Substrate specificity}

Naturally occurring organic forms of sulfur constitute a diverse group of compounds, including sulfur-containing amino acids and sulfonates, as well as organic esters of sulfuric acid (Fitzgerald, 1978). Examples of the latter type of sulfoconjugate include the sulfate esters of simple phenols (arylsulfates), of aliphatic alcohols (alkylsulfates and cholin sulfate), of carbohydrates (e.g. chondroitin sulfate), and of amino acids (e.g. tyrosine sulfate). The arylsulfatase of $V$. carteri was assayed using the chromogenic substrates 4-nitrocatechol sulfate and 5-bromo-4-chloro-3-indolyl sulfate. The possibility that the $V$. carteri arylsulfatase may have a broad spectrum of sulfohydrolase activities has been considered. In addition to the chromogenic 4-nitrocatechol sulfate and 5-bromo-4-chloro-3-indolyl sulfate, tyrosine sulfate was also a substrate. In contrast, carbohydrate sulfates such as Dgalactose 6-sulfate and dextran sulfate (average molecular
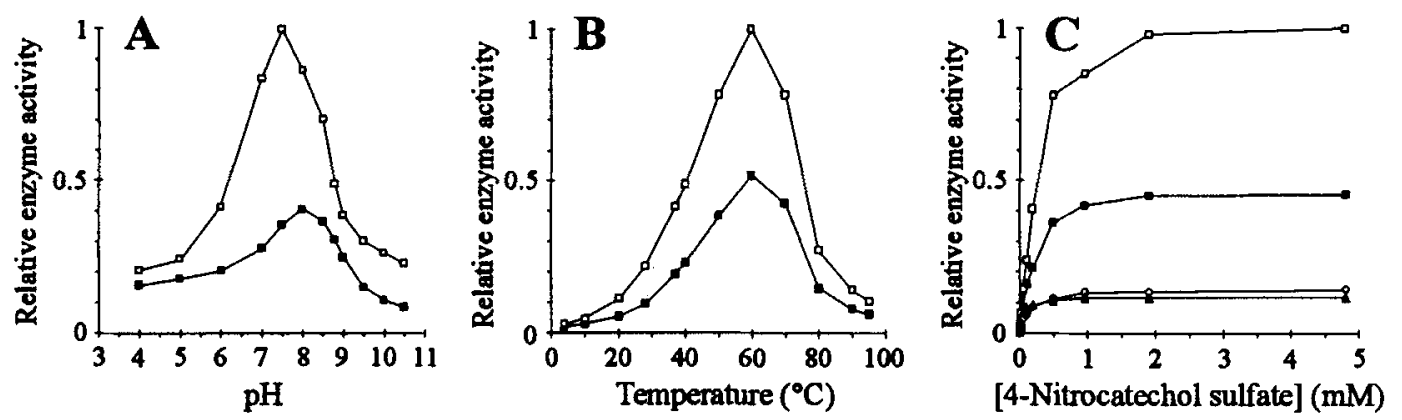

Fig. 6. The enzymic properties of Volvox arylsulfatase. (A) Arylsulfatase activity as a function of pH. (B) The effect of temperature on arylsulfatase activity. (C) Arylsulfatase activity as a function of substrate (4-nitrocatechol sulfate) concentration. The final concentrations of imidazole, $\mathrm{Na}_{3} \mathrm{BO}_{3}$ and $\mathrm{KCN}$ were 10,2 and $10 \mathrm{mM}$, respectively. Reference $(\boldsymbol{\square})$, imidazole $(\square)$; borate $(\mathrm{O}) ; \mathrm{KCN}(\boldsymbol{\Lambda})$. 


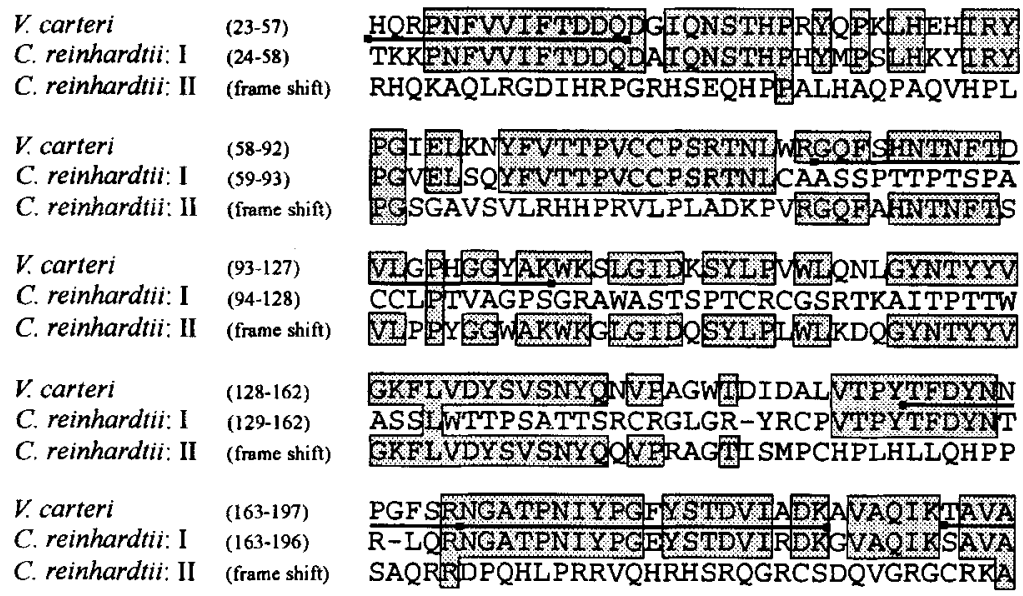

Fig. 7. Alignment and comparision of the $V$. carteri arylsulfatase (amino acid positions 23-197) with the arylsulfatase from $C$. reinhardtii (amino acid positions 24-196). 'Chlamydomonas: I' indicates the published reading frame. 'Chlamydomonas: II' is an amino acid sequence deduced from another reading frame of the arylsulfatase cDNA from Chlamydomonas. The sequenced peptides are underlined.

mass $5 \mathrm{kDa}$ ), alkylsulfates like dodecylsulfate (SDS), and adenosine $5^{\prime}$-phosphosulfate were not accepted as substrates.

A large amount of sulfate is covalently bound to polysaccharides and glycoproteins of the extracellular matrix of $V$. carteri (Wenzl and Sumper, 1987) and might be expected to serve as a reservoir of sulfur in times of deprivation. However, the purified enzyme was unable to release significant amounts of radioactive sulfate from a crude cell lysate previously labeled with ${ }^{35} \mathrm{SO}_{4}{ }^{2-}$. These results indicate that the arylsulfatase from $V$. carteri only utilizes arylsulfates as substrates.

\section{Other properties of the Volvox arylsulfatase}

The Michaelis-Menten constant $\left(K_{\mathrm{m}}\right)$ for the synthetic substrate 4-nitrocatechol sulfate was determined to be $0.27 \mathrm{mM}$ in the presence of $10 \mathrm{mM}$ imidazole and $0.16 \mathrm{mM}$ in the absence of imidazole (Fig. 6C). Imidazole is known to activate the arylsulfatase of $C$. reinhardtii (Lien and Schreiner, 1975). The arylsulfatase from Volvox also shows this property; $10 \mathrm{mM}$ imidazole in the reaction mixture led to increased arylsulfatase activity over the whole $\mathrm{pH}$ range tested, but shifted the $\mathrm{pH}$ optimum from $\mathrm{pH} 8.0$ to $\mathrm{pH} 7.5$ (Fig. 6A).

The arylsulfatase was thermostable, exhibiting a temperature optimum at $60^{\circ} \mathrm{C}$ that was unaffected by the presence or absence of imidazole in the incubation mixture (Fig. 6B). The half-life of enzyme activity was $60 \mathrm{~min}$ at $60^{\circ} \mathrm{C}$ and $\mathrm{pH}$ 8.0.

The presence of substances like $50 \mathrm{mM} \mathrm{Na} \mathrm{SO}_{4}, 5 \mathrm{mM}$ $\mathrm{Na}_{2} \mathrm{SO}_{3}, 5 \mathrm{mM}$ cysteine, $5 \mathrm{mM}$ methionine, $10 \mathrm{mM}$ 2-mercaptoethanol, $10 \mathrm{mM}$ sodium citrate, $10 \mathrm{mM}$ EDTA or $50 \mathrm{mM}$ sodium phosphate (which are known to inhibit many arylsulfatases from other sources) had no effect on the Volvox enzyme. However, $\mathrm{Na}_{3} \mathrm{BO}_{3}$ and $\mathrm{KCN}$ inhibited the enzyme (Fig. $6 \mathrm{C}$ ). $1 \mathrm{mM} \mathrm{Na} \mathrm{BO}_{3}$ or $5 \mathrm{mM} \mathrm{KCN}$ in the reaction mixture gave $50 \%$ inhibition of the arylsulfatase activity.

\section{DISCUSSION}

Much of the sulfur in soil is present as sulfate esters or as sulfonates, rather than the inorganic sulfate that predominates in oceans and rivers (Fitzgerald, 1978). Arylsulfatase activity is found in many organisms and plays an important role in the mineralization of sulfate (Speir and Ross, 1978). The properties of the Volvox arylsulfatase (like its inducible synthesis and its extracellular location) indicate that mineralization of sulfate, by hydrolyzing sulfate esters in response to sulfur deprivation, seems also to be the function of the Volvox enzyme.

Dodgson and Spencer (1957) proposed to subdivide arylsulfatase enzymes into two major groups, the type-I and the type-II arylsulfatases. Type-I arylsulfatases are insensitive to product inhibition $\left(\mathrm{SO}_{4}{ }^{2-}\right)$ and inhibition by phosphate, but are inhibited by $\mathrm{CN}^{-}$, whereas type-II arylsulfatases are inhibited by sulfate or phosphate, but not by $\mathrm{CN}^{-}$. By these criteria, the inducible arylsulfatase from $V$. carteri clearly represents a type-I arylsulfatase.

Based on amino acid sequence data, we have cloned both the genomic DNA and the cDNA encoding arylsulfatase. The derived amino acid sequence is consistent with known properties of the enzyme. The presence of a hydrophobic leader sequence confirms secretion of this enzyme, and the existence of seven potential N-glycosylation sites indicates glycosylation. The protein chemical data (peptide 3, Table 2) prove the post-translational modification of Asn89.

A comparison of the arylsulfatase sequence with sequences in the Swiss-Prot Protein Sequence Database revealed a number of sequence similarities. As expected, the highest similarity found (55.4\% identity over 635 residues) was with the arylsulfatase from $C$. reinhardtii (de Hostos et al., 1989). In addition, significant sequence similarities exist to the human $N$-acetylglucosamine-6-sulfatase $(26.2 \%$ identity over 279 residues) as well as to human arylsulfatase A (22.3\% identity over 220 residues). The region of sequence similarity to both the human enzymes was localized within the C-terminus of the Volvox enzyme (residues 260-520). In contrast, the complete amino acid sequence of the Volvox enzyme shared a high degree of similarity with the Chlamydomonas enzyme. However, there were two significant exceptions. No sequence similarity was found at amino acid positions $81-152$ and $252-294$. As there is no obvious reason for such localized deviations, the possibility of sequencing errors was considered. The deduced amino acid sequence of the Volvox enzyme at amino acid positions 81152 and 252-294 was confirmed by the sequence data obtained earlier from peptides 3 and 4 (Table 2, Fig. 4). There- 
fore, we examined the different reading frames of the published Chlamydomonas cDNA (de Hostos et al., 1989) and recognized that a frame shift would create a sequence highly similar to the Volvox sequence at amino acid positions 81152 (Fig. 7). The same is true for the region at amino acid positions 252-294 (data not shown). Thus, the deviations in both these sequences are most probably caused by sequencing errors. After removal of these deviations by adding or deleting single bases at appropriate places in the mentioned regions of the Chlamydomonas cDNA, an amino acid sequence can be deduced that shares a much higher similarity (69.2\% identity over 633 residues) to the Volvox arylsulfatase than the published Chlamydomonas arylsulfatase sequence does. At present, however, we cannot rule out the possibility that the discrepancy between the amino acid sequences of the Volvox and the Chlamydomonas enzyme, which lies in the N-terminus is the result of four compensating mutations that have occurred during algal evolution.

A remarkable property of the arylsulfatase from Volvox is its insensitivity towards detergents like dodecyl sulfate. Concentrations as high as $1 \%$ SDS do not affect the enzyme activity. This property enables easy detection of the enzyme even in crude cell lysates. Together with a simple enzyme assay using chromogenic substrates, these properties qualify this enzyme as a suitable reporter gene product for the study of differently regulated promoters. The genomic clones now available for this enzyme also include up to $8.5 \mathrm{~kb}$ upstream DNA (clone $\lambda \mathrm{Ar} 52$ ) and therefore most probably encode the information required to obtain sulfur-regulated expression. The highly regulated promoter of the arylsulfatase from $\mathrm{Vol}$ vox is likely to be a helpful tool for expression experiments of cloned genes. Expression should be inducible simply by suspending the transformed Volvox spheroids in sulfate-free growth medium.

We wish to thank Dr R. Deutzmann for sequencing peptides. This study was supported by the Deutsche Forschungsgemeinschaft (SFB 43).

\section{REFERENCES}

Callahan, A. M. \& Huskey, R. J. (1980) Dev. Biol. 80, 419-435.

Davies, J. P., Weeks, D. P. \& Grossman, A. R. (1992) Nucleic Acids Res. 20, 2959-2965.

de Hostos, E. L., Schilling, J. \& Grossmann, A. R. (1989) Mol. \& Gen. Genet. 218, 229-239.

Dodgson, K. S. \& Spencer, B. (1957) in Methods of biochemical analysis (Glick, D., ed.), vol. 4, pp. 211-254, Academic Press, New York.
Dubois, M., Gilles, K. A., Hamilton, J. K., Rebers, P. A. \& Smith, F. (1956) Anal. Chem. 28, 350-356.

Ertl, H., Hallmann, A., Wenzl, S. \& Sumper, M. (1992) EMBO J. $11,2055-2062$.

Ertl, H., Mengele, R., Wenzl, S., Engel, J. \& Sumper, M. (1989) J. Cell Biol. 109, 3493-3501.

Fitzgerald, J. W. (1978) in Sulfur in the environment (Nriagu, J. O., ed.) vol. 2, pp. 391-443, Wiley \& Sons, New York.

Frischauf, A.-M., Lehrach, H., Poustka, A. \& Murray, N. (1983) $J$. Mol. Biol. 170, 827-842.

Frohman, M. A., Dush, M. K. \& Martin, G. R. (1988) Proc. Natl Acad. Sci. USA 85, 8998-9002.

Huskey, R. J., Griffin, B. E., Cecil, P. O. \& Callahan, A. M. (1979) Genetics 91, 229-244.

Kirk, D. L. \& Harper, J. F. (1986) Int. Rev. Cytol. 99, 217-293.

Kirk, M. M. \& Kirk, D. L. (1985) Cell 41, 419-428.

Laemmli, U. K. (1970) Nature 227, 680-685.

Laemmli, U. K. (1977) J. Biol. Chem. 252, 1102-1106.

Lien, T. \& Schreiner, Ø. (1975) Biochim. Biophys. Acta 384, 168179.

Mages, H.-W., Tschochner, H. \& Sumper, M. (1988) FEBS Lett. 234, 407-410.

Mages, W. (1990) Ph. D. thesis, University Regensburg, Germany.

Provasoli, L. \& Pintner, I. J. (1959) in The ecology of algae (Tyron, C. A. \& Hartman, R. T., eds), Special Publication no. 2, pp. 8496, Pymatuning Laboratory of Field Biology, University of Pittsburgh, Pittsburgh.

Rochaix, J.-D., van Dillewijn, J. \& Rahire, M. (1984) Cell 36, 925931.

Sambrook, J., Fritsch, E. F. \& Maniatis, T. (1989) Molecular cloning: a laboratory manual, 2nd edn. Cold Spring Harbor Laboratory Press, Cold Spring Harbor, NY.

Sanger, F., Nicklen, S. \& Coulson, A. R. (1977) Proc. Natl Acad. Sci. USA 74, 5463-5467.

Schiedlmeier, B., Schmitt, R., Müller, W., Kirk, M. M., Gruber, H., Mages, W. \& Kirk, D. L. (1994) Proc. Natl Acad. Sci. USA, in the press.

Schmitt, R., Fabry, S. \& Kirk, D. L. (1992) Int. Rev. Cytol. 139, 189-265.

Speir, T. W. \& Ross, D. J. (1978) in Soil enzymes (Burns, R. G., ed.) pp. 197-250, Academic Press, London.

Starr, R. C. (1970), Dev. Biol. Suppl. 4, 59-100.

Starr, R. C. \& Jaenicke, L. (1974) Proc. Natl Acad. Sci. USA 71, $1050-1054$.

Sumper, M., Berg, E., Wenzl, S. \& Godl, K. (1993) EMBO J. 12, $831-836$.

Terho, T. T. \& Hartiala, K. (1971) Anal. Biochem. 41, 471-476.

Tschochner, H., Lottspeich, F. \& Sumper, M. (1987) EMBO J. 6, $2203-2207$

Vaskovsky, V. E., Kostetsky, E. J., Svetashev, V. I., Zhukova, I. G. \& Smirnova, G. P. (1970) Comp. Biochem. Physiol. 34, 163-177.

Wenzl, S. \& Sumper, M. (1986) Dev. Biol. 115, 119-128.

Wenzl, S. \& Sumper, M. (1987) in Algal development (Wiessner, W., Robinson, D. G. \& Starr, R. C., eds) pp. 58-65, Springer, Berlin. 